\title{
Filozoficzne podstawy koncepcji samorealizacji człowieka w myśli Osho
}

\author{
Artur Hrehorowicz
}

\section{Wprowadzenie}

Samorealizacja i związane z nią pojęcie rozwoju osobistego stały się ostatnio bardzo popularne. Chociaż potocznie kojarzy się je często z nurtami parareligijnymi czy wręcz ezoterycznymi, takimi jak New Age albo buddyzm zen, wbrew pozorom stanowią też przedmiot badań wielu nauk humanistycznych, na przykład psychologii, socjologii czy filozofii. Zagadnienie jednostkowej samorealizacji, ujmowane w sposób filozoficzny, stanowi również jeden z centralnych problemów myśli indyjskiego guru Osho (1931-1990). Jest to myśliciel mało znany w Polsce, obecnie trudno też mówić o jakiejś pogłębionej recepcji jego prac ${ }^{1}$. Może to wynikać z tego, że Osho kojarzony jest głównie ze swojej publicznej działalności jako guru, a niewiele wiadomo o jego karierze filozofa akademickiego. Jednak, jak zauważa George D. Chryssides, Osho „nie był filozofem amatorem”,

\footnotetext{
1 Pierwsza w Polsce praca naukowa dotycząca życia i nauczania Osho została napisana przez religioznawcę Jacka Sieradzana. Jest to rozdział w monografii pt. Od kultu do zbrodni. Ekscentryzm i szaleństwo w religiach XX wieku (w tej kwestii zob. tenże, Ośo Radżniś, czyli szaleństwo jako metoda, w: tegoż, Od kultu do zbrodni. Ekscentryzm i szaleństwo w religiach XX wieku, Wydawnictwo KOS, Katowice 2006, s. 115-189).

2 G.D. Chryssides, Exploring New Religions, wyd. Continuum International Publishing Group, London 1999, s. 207-208.
} 
posiadał rzetelne wykształcenie akademickie $\mathrm{z}$ filozofii ${ }^{3}$, co niewątpliwie miało wpływ na kształtowanie się jego myśli, w której silnie obecna jest problematyka filozoficzna.

W swojej refleksji Osho wyróżnia dwa etapy jednego procesu ewolucji świata i człowieka: nieświadomy i świadomy. „Ewolucja nieświadoma” ma charakter mechaniczny i deterministyczny. Jest to automatyczny, samoistny proces, który poprzedza i umożliwia to, co Osho określa jako „ewolucję świadomą”, czyli proces świadomego rozwoju każdego człowieka. Rodzajem ewolucji świadomej jest samorealizacja. Wyjaśniając to zjawisko, posługuje się on również terminami bliskoznacznymi, takimi jak spełnienie, wzrost, rozwój czy rozkwit. Trzeba też zaznaczyć, że interesuje go głównie samorealizacja, etap nieświadomy zaś jest przywoływany jedynie w celach porównawczych, to znaczy po to, aby poprzez wskazanie różnic lepiej wyjaśnić, na czym polega proces jednostkowego wzrostu.

Głównym celem niniejszej pracy jest przedstawienie filozoficznych podstaw koncepcji samorealizacji w myśli Osho. Interesują mnie tutaj filozoficzne aspekty zagadnienia samorealizacji człowieka, pojmowanego jako podmiot autonomiczny, nie zaś kwestie psychologiczne czy pedagogiczne. W swoich analizach ukażę antropologiczne i ontologiczne podstawy tej koncepcji i będę bronić tezy, że Osho proponuje zbliżone do Nietzscheańskiego oraz Sartre’owskiego ujęcie ewolucyjne i jakościowe ${ }^{4}$, zgodnie z którym przychodzimy na świat jako istoty niedokończo-

3 Osho w latach 1952-1955 ukończył studia licencjackie z filozofii w Koledżu DN Jain w Jabalpur w Indiach. Był zdolnym studentem. Od 1951 roku do 1968 roku brał regularny udział w debacie filozoficznej na dorocznym ogólnoindyjskim zjeździe międzywyznaniowym Sarva Dharma Sammelan w Jabalpur, organizowanym przez dżinistów, w której też odnosił sukcesy (np. zwyciężył debatę w roku 1955). Ukończył z wyróżnieniem studia z filozofii w 1957 roku na Uniwersytecie w Sagar, otrzymując dyplom magistra. Po studiach został nauczycielem akademickim, najpierw na krótko w Koledżu Sanskryckim w Raipur, a następnie od 1958 roku do 1966 roku wykładał filozofię na Wydziale Sztuk Pięknych Uniwersytetu Jabalpur. W tym czasie w 1960 roku awansował na profesora. Zob. J. Sieradzan, Od kultu do..., dz. cyt., s. 121; V. Joshi, The Awakened One, Harper and Row, San Francisco 1982, s. 185.

4 Taka analogia jest uzasadniona, ponieważ Osho dobrze zna filozofię zachodnią i wielokrotnie w swoich wystąpieniach otwarcie powołuje się na takich myślicieli jak Nietzsche czy Sartre, którymi się inspiruje. Zna niewątpliwie Tako rzecze Zaratustra Nietzschego, o czym może świadczyć chociażby to, że w dniach od 26 marca do 19 kwietnia 1987 roku wygłosił w języku angielskim cykl 43 wykładów dla swoich uczniów (był to jego własny komentarz do tego dzieła). Wykłady te po śmierci Osho w niezmienionej treści zostały po raz pierwszy opublikowane w dwóch tomach pt. A God That Can Dance oraz Zarathustra: The Laughing Prophet. W Polsce ukazał się dotąd jedynie pierwszy z nich w 2007 roku pt. Zaratustra: Bóg, który tańczyć potrafi. Komentarz do „Tako rzecze Zaratustra” Friedricha Nietzschego. Z kolei Hugh B. Urban zwraca 
ne i niekompletne. Jednocześnie pokażę, że Osho nie ogranicza się do rozważań teoretycznych, ale przyjęte rozwiązania ontologiczne i antropologiczne mają cel praktyczny i służą wypracowaniu takich koncepcji etycznej i teorii wartości, które dają nam wskazówki i tworzą odpowiednie warunki ułatwiające nam samorealizację. Zwrócę szczególną uwagę na to, jakie znaczenie dla tego procesu mają nasze świadome postępowanie, wolność oraz odpowiedzialność.

Ze względu na fakt, że klasyczna myśl hinduska jest słabo znana polskiemu czytelnikowi, zacznę od krótkiego przybliżenia jej najważniejszych założeń i sposobu, w jaki Osho ustosunkowuje się do dalekowschodniej tradycji, z której w pewnej mierze się wywodzi. Choć filozofia hinduska posiada wiele odmian i odłamów, które różnią się między sobą pojmowaniem Boga, wizją powstania świata, koncepcją życia duchowego oraz praktykami religijnymi, to jednak można wskazać kilka „cech wspólnych "panindyjskiego» światopoglądu”. Należą do nich takie elementy, jak porządek kastowy w społeczeństwie, ogromny szacunek dla świętych ksiąg (Wedy i Upaniszady) czy wiara w prawo karmana, które działa zarówno na poziomie jednostkowym, jak i zbiorowym, a nawet kosmicznym, i z którym „muszą się liczyć nawet bogowie”. Determinuje ono i wyznacza kierunek naszych działań, które „są z sobą sprzęgnięte”7, określa także to, czym jesteśmy, a co zależy „od sumy wszystkich uczynków, myśli i postanowień nagromadzonych przez subtelny podmiot świadomościowy", czyli nasze głębokie „ja”.

Do tradycyjnych elementów hinduskiego myślenia można zaliczyć także operowanie ideą cykliczności i wynikającą z niej wiarę w reinkarnację, rozumianą jako dążenie do wyzwolenia duszy (samsara i moksza) i uwolnienia się z kręgu narodzin. Efektem tego było postrzeganie filozofii w kategoriach pragmatycznych. Dla Hindusów była to bowiem w większym stopniu metoda zbawienia, czyli odmiana soteriologii, a nie czysta teoria, której celem jest jedynie opisywanie

uwagę, że myśl Osho zawiera idee zaczerpnięte m.in. od Sartre’a (zob. tenże, Zorba the Buddha Capitalism, Charisma and the Cult of Bhagwan Shree Rajneesh, „Religion” 1996, nr 26, s. 169).

5 M. Kudelska, Filozofia Indii - kilka uwag wstępnych, w: Filozofia Wschodu, red. B. Szymańska, Wydawnictwo Uniwersytetu Jagiellońskiego, Kraków 2001, s. 13. Odwołuję się także do następującego opracowania: Th. Schweer, Hinduizm: powstanie - dzieje - nauka, tłum. P. Pachciarek, Verbinum, Warszawa 2003, s. 8.

$6 \quad$ M. Kudelska, Filozofia Indii..., dz. cyt., s. 14.

7 Tamże, s. 14.

8 Tamże, s. 15. 
czy wyjaśnianie rzeczywistości ${ }^{9}$. Co prawda nie uznają oni charakterystycznego dla myśli biblijnej modelu stworzenia z nicości (creatio ex nihilo), przyjmują jednak znane z filozofii greckiej (np. platońskiej) rozróżnienie na niedoskonały świat zjawiskowy, który jest przejawem, emanacją albo odbiciem bardziej doskonałej rzeczywistości absolutnej ${ }^{10}$.

Jaki jest stosunek Osho do powyższych poglądów? Przede wszystkim sprzeciwia się on dzieleniu i kategoryzowaniu filozofii na wschodnią i zachodnią, chińską czy niemiecką itd. Uważa bowiem, że filozofia, podobnie jak nauka, jest jedna. Świadczy o tym następujący fragment, w którym mówi, jak rozumie filozofię hinduską:

Czym jest hinduska filozofia? Po pierwsze, filozofia jest po prostu filozofią. Nie może być hinduska, chińska, niemiecka czy japońska... Filozofia to filozofia. Dlaczego pan mnie o to pyta? Filozofia to filozofowanie, a jakie ma znaczenie, czy człowiek filozofuje w Grecji, w Indiach czy w Jerozolimie? Geografia nie ma na to wpływu, nie mają na to wpływu granice czy narody. Na początku proszę odrzucić w pytaniu słowo „hinduska”, które jest tu nie na miejscu. Proszę zapytać mnie: „Czym jest filozofia”?"11.

Jest krytyczny wobec tradycyjnych wierzeń hinduskich i w ogóle wobec religii. Odrzuca wiarę w istnienie bóstw hinduistycznych i autorytet świętych ksiąg hinduizmu (które jednak bardzo dobrze znał). Uważa, że Bóg to tylko rodzaj projekcji ludzkiego umysłu, religie zaś, które wymagają od ludzi wiary oraz wpajają im przekonania metafizyczno-teologiczne, uznaje za „dziecinne”. Ponadto neguje prawo karmana, ponieważ uważa, że nauka nigdy go nie potwierdziła, a zatem wiara w karmiczne zależności jest sprzeczna $\mathrm{z}$ logiką. Osho uznaje jednak ideę reinkarnacji i podobnie jak wyznawcy hinduizmu głosi potrzebę osiągniecia ostatecznego wyzwolenia, czyli ostatecznej wolności (tzw. mokszy), choć twierdzi, że należy do niej dążyć inną drogą, niż zakłada tradycja religijna. Bliskie jest mu także hinduistyczne rozumienie relacji ciało-dusza. Podziela w dużej mierze przekonanie o praktycznym charakterze filozofii. Odwołuje się też do kluczowego dla hinduizmu terminu, jakim jest tzw. kundalini. Oznacza ono zwi-

Tamże, s. 16.

Tamże, s. 13.

Osho, Magia szacunku do siebie. Rozbudzanie świadomości, tłum. B. Jurkevich, Czarna Owca, Warszawa 2020, s. 144. 
niętą energię (moc), która znajduje się w każdym człowieku. Można ją obudzić za pomocą medytacji bądź praktyk fizycznych takich jak joga ${ }^{12}$.

Opisując możliwości rozwoju i samorealizacji człowieka, Osho łączy ze sobą elementy mistyki i filozofii Wschodu, Zachodu oraz psychologii humanistycznej i psychodynamicznej. Swoją koncepcję samorealizacji tworzy jednak w znacznym stopniu w oparciu o poglądy tradycji humanistyki zachodniej oraz mistyki orientalnej, w znikomym stopniu odwołując się do opartej na religii filozofii hinduistycznej. Osho próbuje w swoim nauczaniu doprowadzić do dialogu, w którym dochodzi do spotkania tradycji Wschodu i Zachodu. Duchowość zostaje dopełniona rozumnością, rozum wzbogacony zostaje o głęboką duchowość itd. Osho uważa, że wtedy będzie możliwy rozwój nowego, zintegrowanego, wielowymiarowego i żyjącego całą pełnią człowieka określanego przez niego jako „Zorba-Budda”13.

\section{Ogólne rozumienie człowieczeństwa}

Filozoficznych podstaw koncepcji samorealizacji w myśli Osho należy szukać w jego antropologii. Osho uważa, że człowiek jest bytem złożonym, a wszystkie elementy jego struktury są harmonijnie zintegrowane, współdziałające. Składa się on $\mathrm{z}$ ciała, z naturalnego potencjału wyjściowego (tj. z predyspozycji, zdolności i talentów), który się stale aktualizuje, i z wielości aktualizujących się i zaktualizowanych składowych. Potencjał człowieka wraz z jego cielesnością uznaje Osho za „pierwszą naturę”, „prawdziwą naturę” w nim. Ma ona charakter indywidualny, jednostkowy. Oznacza to, że jest niepodzielna, nie rozpadnie się na części, gdyż jest jedną całością. Stanowi ona wyraźne przeciwieństwo ukształtowanej - w wyniku procesu socjalizacji, wpływu wychowania, kształcenia - osobowości człowieka, która jest czymś sztucznym i ulegającym dezintegracji.

Osho uważa, że w odróżnieniu od zwierzęcia, które rodzi się dokończone i „pozostaje takie samo przez całe życie”, człowiek w momencie przyjścia na

12 O tym, czym jest kundalini, zob. J. Świtkowski, Kwiaty lotosu i kundalini a gruczoly dokrewne studium krytyczne, Lotos, Kraków 1937.

13 Więcej na ten temat zob. A. Hrehorowicz, Wizja człowieka u Osho, wyd. Eryk Kowalczyk, Olsztyn 2016. 
świat nie jest w pełni ukształtowaną istotą ${ }^{14}$. Osho określa człowieka jako „zwierzę niedoskonałe”15 oraz „zwierzę ewolucyjne”16. Znajdujemy tutaj analogię do poglądów Nietzschego, według którego człowiek jest „zwierzęciem jeszcze nie ustalonym"17.

W swoich analizach natury ludzkiej Osho dokonuje przeciwstawienia potencjalności i realizacji. Odrzuca metafizyczną, deterministyczną próbę ujmowania istoty człowieka w sposób esencjalistyczny i kwestionuje postrzeganie jej w kategoriach jakiejś immanentnej, wrodzonej, gotowej, niezmiennej konstytucji, która miałaby niejako a prori determinować nasze istnienie i działanie ${ }^{18}$. Uważa on, że o naturze ludzkiej należy raczej myśleć jako o potencjale rozwojowym, którego urzeczywistnienie to w dużej mierze proces przygodny, zależny przede wszystkim od aktywności własnej urzeczywistniającej go osoby ${ }^{19}$. Według Osho człowiek istnieje w sposób zupełnie odmienny od zwierzęcia czy tė̇ rzeczy. Przypomina on „rzucony projekt”, zgodnie z tezą Sartre’a, że „istnienie poprzedza istotę"20.

Osho uznaje potencjał za pierwotny, źródłowy aspekt człowieczeństwa. Zawiera on zarówno uniwersalne dyspozycje i talenty, które są wspólne wszystkim ludziom, takie jak mówienie, myślenie czy świadomość, jak też takie potencje,

14 Zob. Osho, Transformacja przez tantrę, tłum. H. Smagacz, Nowy Horyzont, Warszawa 2010, s. 58; tenże, Przeznaczenie, wolność, dusza. Jaki sens ma życie?, tłum. B. Jurkevich, Czarna Owca, Warszawa 2017, s. 150, 179, 180, 184; tenże, Księga zrozumienia. Własna droga do wolności, tłum. B. Grabska-Siwek, Czarna Owca, Warszawa 2013, s. 257-258; tenże, Pytania płynace z serca, tłum. B. Jurkevich, Czarna Owca, Warszawa 2019, s. 52; tenże, Wielka ksiegga sekretów, tłum. J. Janisiewicz, Czarna Owca, Warszawa 2011, s. 142.

15 Tenże, Przeznaczenie..., dz. cyt., s. 150.

16 Tenże, Wolność. Odwaga bycia soba, tłum. H. Smagacz, Czarna Owca, Warszawa 2014, s. 69.

17 Zob. M. Buber, Problem człowieka, tłum. J. Doktór, Wydawnictwo Naukowe PWN, Warszawa 1993, s. 41.

18 Zob. Osho, Miłość, wolność, samotność. Nowe spojrzenie na zwiąki między ludźmi, tłum. B. Jurkevich, Czarna Owca, Warszawa 2015, s. 133-134; tenże, Przeznaczenie..., dz. cyt., s. 178-179; A. Hrehorowicz, Aksjologiczne źródła etyki u Osho, „Humanistyka i Przyrodoznawstwo” 2017, nr 23, s. 265.

19 Zob. Osho, Ksiegga zrozumienia..., dz. cyt., s. 257; tenże, Miłość, wolność..., dz. cyt., s. 135; tenże, Przeznaczenie..., dz. cyt., s. 150; tenże, Życie jako podróż. Czy można znaleźć prawdziwe szczęście $w$ codzienności?, tłum. B. Jurkevich, Czarna Owca, Warszawa 2018, s. 9; tenże, Transformacja..., dz. cyt., s. 58; tenże, Pytania..., dz. cyt., s. 52; A. Hrehorowicz, Aksjologiczne..., dz. cyt., s. 265.

Zob. Osho, Miłość, wolność..., dz. cyt., s. 133-134; tenże, Przeznaczenie..., dz. cyt., s. 178-179; tenże, Życie jako podróż..., dz. cyt., s. 9; tenże, Pytania..., dz. cyt., s. 52, 158, 159; J.-P. Sartre, Egzystencjalizm jest humanizmem, tłum. J. Krajewski, Warszawskie Wyd. Literackie Muza, Warszawa 1998, s. 23, 26, 27. 
które są przypisane tylko do określonej jednostki i których nie ma żaden inny człowiek. Natura ma charakter aktywny, dynamiczny, plastyczny, dlatego uzyskanie w pełni określonej formy jest zawsze wytworem pewnej określonej aktywności człowieka podejmowanej w kontekście całości jego życia. To właśnie plastyczność ludzkiego potencjału umożliwia zmodyfikowanie ukształtowanej wcześniej w wyniku własnej aktywności albo oddziaływań socjalizacyjnych formy. W jakim jednak stopniu? Osho podchodzi do tego problemu w sposób optymistyczny, ponieważ nie wyklucza możliwości nawet radykalnej przemiany wewnętrznej jednostki ${ }^{21}$. Inni filozofowie, tacy jak np. John Dewey, uważali, że jest to wątpliwe, a w każdym razie dyskusyjne. Według niego zakres i charakter modyfikacji formy jednostki jest nieustannie ograniczany przez jej wcześniejsze określenia i determinacje ${ }^{22}$. Niemniej jednak uznaje on, podobnie jak i Osho, że nie można z góry, a prori, z całą pewnością przewidzieć, jaką formę w przyszłości przybierze egzystencja danej jednostki ${ }^{23}$.

Przyjęta przez Osho definicja pojęcia „samorealizacji” opiera się na powyższej wizji natury ludzkiej (tego, kim jest człowiek) i ma charakter „egzystencjalny”. Według niego „samorealizacja oznacza, że stałeś się tym, kim miałeś się stać. Urodziłeś się jako nasienie i rozkwitłeś. Doszedłeś do pełnego rozwoju, pełni wewnętrznego rozwoju, do wewnętrznego końca"24. Jak sam podkreśla, inspiruje się tutaj poglądami amerykańskiego psychologa Abrahama Maslowa, który także określa samorealizację jako zdolność danej jednostki do jak najpełniejszego urzeczywistnienia swojego naturalnego potencjału ${ }^{25}$.

Czołową rolę w procesie samorealizacji człowieka u Osho odgrywają dwie wskazane przez niego dyspozycje antropologiczne: świadomość i wolność. Według Osho ewolucyjnym podłożem rozwoju człowieka jest właściwa dla jego egzystencjalnej struktury świadomość, która wskazuje na możliwość wolnego wyboru. Wraz z wolnością i świadomością pojawia się niepewność dotycząca rozwoju, który może nastąpić albo nie ${ }^{26}$. Rozwój człowieka to właśnie rodzaj „ewolucji świadomej”, czyli świadomego wysiłku jednostki do realizacji siebie.

${ }_{21}$ Zob. Osho, Miłość, wolność..., dz. cyt., s. 133-134; tenże, Przeznaczenie..., dz. cyt., s. 178-180.

22 Zob. Ł. Nysler, Natura ludzka - jaźń - indywidualność. Filozoficzno-antropologiczne i etyczne podstawy koncepcji demokracji Johna Deweya, „Studia Philosophica Wratislaviensia” 2007, Vol. II, fasc. 1, s. 58.

23 Zob. Osho, Życie jako podróż..., dz. cyt., s. 9.

24 Tenże, Wielka ksiegga..., dz. cyt., s. 142; por. z tenże, Ksiegga zrozumienia..., dz. cyt., s. 257.

25 Zob. tenże, Wielka księga..., dz. cyt., s. 142.

26 Zob. A. Hrehorowicz, Aksjologiczne..., dz. cyt., s. 269. 
Nie jest to proces konieczny, nieuchronny, jak w przypadku zwierzęcia, które jest biologicznie zdeterminowane i „zaprogramowane” do wzrostu, ponieważ ludzki potencjał nie jest w stanie urzeczywistnić się samoistnie ${ }^{27}$. Zrealizowanie go zależy w pierwszej kolejności od świadomego działania indywiduum. Wobec tego Osho podkreśla, że samorealizacja staje się zjawiskiem indywidualnym, ponieważ człowiek musi chcieć podjąć się swojego rozwoju i tworzenia siebie, aby proces ten mógł się w ogóle zacząć ${ }^{28}$. Ontologiczna wolność człowieka warunkuje zatem jego rozwój, jest tym czynnikiem, od którego się on zaczyna i bez którego nie byłby możliwy. Kiedy rozwój staje się efektem świadomego działania, wraz z nim pojawia się także konieczność dokonywania jakichś kolejnych wyborów. Osho podziela expressis verbis przekonanie Sartre’a na temat wolności człowieka, zgodnie z którym „człowiek jest skazany na wolność”29. Oznacza to, że zawsze stoimy w obliczu jakiegoś wyboru czy decyzji i nie możemy wyzbyć się swojej wolności. Zrezygnowanie z niej także jest wyborem ${ }^{30}$. To właśnie z powodu świadomości i wolności jednostki ludzkiej realizacja jej potencjału zawsze będzie konkretna i indywidualna, i może być nawet radykalnie odmienna od realizacji innych ludzi.

\section{Religie jako przeszkody na drodze ku samorealizacji}

Koncepcja samorealizacji Osho wynika nie tylko z pewnego wyobrażenia o naturze ludzkiej. Za jedną z przeszkód na drodze samorealizacji Osho uznaje tė popularne zwłaszcza w filozofii zachodniej koncepcje, zakładające, że człowiek i wszechświat zostały stworzone przez Boga. Choć czerpie on tutaj także z tradycji religii Dalekiego Wschodu, jego koncepcja ma charakter nieco zbliżony do Nietzscheańskiej czy Sartre'owskiej. Oznacza to, że należy ją rozumieć nie tyle w kategoriach metafizycznych sensu stricto, np. jako próbę filozoficznego uzasadnienia ateizmu, ile raczej w kategoriach krytyki pewnych wyobrażeń kulturowych, które leżą u źródeł przyjętych w społeczeństwie wzorców zachowań, życia czy norm moralnych.

\footnotetext{
Zob. tamże.

Zob. Osho, Przeznaczenie..., dz. cyt., s. 180; A. Hrehorowicz, Aksjologiczne..., dz. cyt., s. 270.

Zob. Osho, Psychologia ezoteryki, tłum. i wyd. Samira, Łódź 1995, s. 20; tenże, Wielka księga..., dz. cyt., s. 142.

30 Zob. tenże, Psychologia..., dz. cyt., s. 12; A. Hrehorowicz, Aksjologiczne..., dz. cyt., s. 265.
} 
Osho twierdzi, że stworzenie oraz rozwój nie mogą współistnieć ze sobą w jednym bycie, gdyż wzajemnie się wykluczają ${ }^{31}$. Stworzenie oznacza bowiem powołanie do istnienia czegoś skończonego, natomiast rozwój jest możliwy tylko wtedy, gdy coś nie jest skończone i doskonałe ${ }^{32}$. A zatem idea stworzenia i rozwój człowieka są wewnętrznie sprzeczne. Osho argumentuje tutaj w sposób nieco zbliżony do Sartre’a, który w swojej egzystencjalistycznej ontologii odróżniał „byt w sobie” oraz „byt dla siebie”. Pierwsza z tych kategorii określa sposób istnienia świata przedmiotowego i materialnego, który jako odpowiednik kartezjańskiej substancji rozciągłej jest zawsze taki sam, tożsamy ze sobą itd., a druga odnosi się do świadomej ludzkiej egzystencji, która podlega zmianie i w związku z tym pozostaje zawsze niejako niedokończona i niedookreślona (nie jest konkretna, jakaś, taka a nie inna) ${ }^{33}$.

Podobnie jak Sartre, Osho zwraca uwagę na niektóre konsekwencje tego zagadnienia dla popularnej filozoficznej kwestii istnienia Boga. Uważa on, że nie tylko nie rozwiązuje ona problemu człowieka, ale wręcz go pogłębia. Jeśli bowiem człowiek został stworzony, to nie może być wolny, gdyż stworzenie wiąże się z odebraniem jednostce możliwości dokonywania swobodnych wyborów, która stanowi podstawowy warunek jej samostanowienia i decyduje o jej człowieczeństwie $^{34}$. Na przykład judeochrześcijańska koncepcja Boga zakłada, że człowiek został stworzony według boskiego zamysłu oraz że Bóg w akcie stwórczym określił jego naturę. Osho odwołuje się tutaj do obrazu garncarza lepiącego garnek ${ }^{35}$. Także Sartre porównuje Boga stwarzającego człowieka zgodnie z aprioryczną ideą tkwiącą w swoim umyśle do rzemieślnika wytwarzającego rozcinacz zgodnie z posiadanym wcześniej projektem ${ }^{36}$. Obaj myśliciele zwracają uwagę na to, że między ideą preegzystującą w umyśle Boga a stworzeniem człowieka zachodzi ścisła zależność - idea stanowi tu uniwersalny wzorzec dla sposobu stworzenia ludzkiej natury ${ }^{37}$. W przekonaniu Osho samo istnienie takiej uprzedniej natury oznacza, że należy rozumieć ją w sposób esencjalistyczny, czyli jako uniwersal-

\footnotetext{
Zob. Osho, Ksiega zrozumienia..., dz. cyt., s. 147.

32 Zob. tamże, s. 147-148; tenże, Ksiegga ego. Wolność od iluzji, tłum. P. Karpowicz, Czarna Owca, Warszawa 2019, s. 26.

33 Zob. T. Jaroszewski, Filozofia egzystencji a etyka sytuacyjna Jean Paul Sartre’a, „Etyka” 1970, nr 7, s. $43,44$.

34 Zob. Osho, Ksiega zrozumienia..., dz. cyt., s. 148.

35 Zob. tamże, s. 145.

36 Zob. J.-P. Sartre, Egzystencjalizm..., dz. cyt., s. 22-23; T. Jaroszewski, dz. cyt., s. 48.

37 Zob. J.-P. Sartre, Egzystencjalizm..., dz. cyt., s. 25.
} 
ny, ponadczasowy, gotowy i stały program, który determinuje sposób egzystencji jednostki ${ }^{38}$. Jak zauważa Osho, sprawia to, że zawsze będzie ona „niewolnikiem”, a jej „wolność pustym słowem”39, ponieważ będzie ona postępować tylko w tym zakresie, jaki przewidział dla niej stwórca.

Dlatego też Osho uważa, że odrzucenie Boga jest nie tylko przejawem ludzkiej wolności, ale także jednym z podstawowych warunków umożliwiających samorealizację. Przytacza on stwierdzenie Nietzschego: „Bóg umarł i człowiek jest wolny" ${ }^{\prime 4}$. Choć uważa je za trafną analizę świadomości współczesnego człowieka, zaznacza, że wymaga ono pewnego dopowiedzenia ${ }^{41}$. Nietzsche nie brał pod uwagę, zdaniem Osho, takich religii jak dżinizm, buddyzm czy taoizm, w których nie uznaje się Boga jako bytu osobowego, a mimo to ich wyznawcy nie mogą być wolni ${ }^{42}$. Przez afirmację wolności (w sensie antropologicznym) Osho rozumie to, że człowiek może żyć zgodnie ze swoją prawdziwą „naturą”, co pozwala mu utrzymać swoją wewnętrzną tożsamość oraz pozostać w harmonii ze światem. Religie z kolei dążą do psychicznego i duchowego zniewolenia ludzi, stosując w tym celu różne metody represjonowania ludzkiej psychiki i aktywności. Mechanizm represji Osho wyjaśnia w sposób zbliżony do ujęcia freudowskiego, zgodnie z którym polega ona na uwewnętrznieniu i nadmiernej samokontroli własnych stanów wewnętrznych. Jej celem jest nastawienie człowieka przeciwko samemu sobie, aby nie akceptował on siebie takim jakim jest i potępiał jakieś elementy swojego bytu (np. instynkt, zmysłowość, seksualność itd.), co ma doprowadzać do wytworzenia w nim konfliktu wewnętrznego ${ }^{43}$. Często dzieje się to za cenę utraty poczucia swojej integralności i tożsamości podmiotowej.

Represja jest efektem właściwego danej religii porządku aksjologicznego (hierarchii wartości), którego należy przestrzegać. To, jak ustosunkowujemy się do samych siebie, zależy bowiem od naszych poglądów, a te z kolei są warunkowane przez właściwą dla danej religii, a więc jednostronną moralność. To właśnie dlatego religiom udaje się niekiedy zaangażować jednostkę w walkę o sprawy, które

\footnotetext{
Zob. Osho, Ksiega zrozumienia..., dz. cyt., s. 149.

Tenże, Ksiega zrozumienia..., dz. cyt., s. 138.

40 Tamże, s. 138; tenże, Wolność..., dz. cyt., s. 39. Nietzsche stwierdza: „Bóg nie żyje” (niem. „Gott ist tot"). Sformułowanie to pojawia się w Wiedzy radosnej - w sekcji 108 (Nowe walki), 125 (Człowiek oszalały) oraz w sekcji 343 (W sprawie naszej pogody). Występuje też w jego dziele Tako rzecze Zaratustra. Książka dla wszystkich i dla nikogo.

41 Zob. Osho, Ksiega zrozumienia..., dz. cyt., s. 138.

42 Zob. tamże, s. 138, 139; tenże, Wolność..., dz. cyt., s. 39-40.

43 Zob. tenże, Księga zrozumienia..., dz. cyt., s. 24.
} 
mogą być sprzeczne z przyjętą przez nią wizją człowieka. Osho podkreśla, że traktowanie komplementarnych sfer ludzkiego funkcjonowania jako oddzielnych, a nawet przeciwstawnych sobie, jest bardzo szkodliwe, gdyż staje się przyczyną kolejnych redukcji i podziałów. Ten brak wewnętrznego zintegrowania powoduje chociażby to, że człowiekowi trudno jest akceptować i kochać siebie i innych, a w konsekwencji nie może osiągnąć szczęścia. Według Osho wewnętrzny podział przekłada się także na nasz sposób codziennego funkcjonowania w świecie, ponieważ projektujemy go na całą egzystencję, myśląc o niej w kategoriach dualizmu i wykluczających się wzajemnie opozycji. W rezultacie jedna część nas będzie czegoś pragnęła, inna natomiast będzie temu przeciwna ze względu na wyznawane wartości religijne. Taka postawa prowadzi więc do blokowania aktualizacji wielu naszych predyspozycji, staje się źródłem wewnętrznych napięć i neuroz, grozi popadnięciem w skrajności. Z drugiej strony, jeśli postąpimy ostatecznie tak jak chcemy, wbrew wpajanym nam w procesie wychowania zasadom, one i tak będą oddziaływać i wzbudzą w nas poczucie winy ${ }^{44}$. Osho uważa, że będziemy wtedy żyć w poczuciu własnej niższości, doznając pragnienia porządku i autorytetu. Pragnąc uwolnić się od dręczącego nas poczucia winy, zwracamy się o pomoc do osób duchownych, uzależniając swoje życiowe wybory od ich wskazań i $\operatorname{rad}^{45}$. Oni jednak w przekonaniu Osho nie są w stanie pomóc nam w odkryciu naszych wrodzonych możności, potencjału oraz w zaakceptowaniu siebie i w byciu sobą. Będą starali się urobić nas na swoją modłę, zanim w ogóle zorientujemy się, kim jesteśmy. W tym celu oczekują od nas realizacji pewnych ideałów i obowiązków. Postulują na przykład, byśmy stali się naśladowcami proroków czy świętych. Zdaniem Osho prowadzi to do rozmycia poczucia odpowiedzialności osoby za siebie, a także do zniszczenia tożsamości podmiotowej i wewnętrznej autonomii osoby. Jego zdaniem we wszystkich religiach tkwi obawa, że jeśli człowiek odkryje, kim naprawdę jest, nieuchronnie stanie się indywidualistą, żyjącym według własnych zasad i wartości, nie zaś według narzuconej moralności konfesyjnej. Kiedy się tacy stajemy, nie potrzebujemy życiowego kierownictwa, a religia traci możliwość używania istot ludzkich jako narzędzi do realizowania własnych celów ${ }^{46}$.

${ }_{44}$ Zob. tamże, s. 24, 25; tenże, Równowaga ciała i umysłu, tłum. B. Jurkevich, Ravi, Łódź 2005, s. 40.

45 Zob. tenże, Równowaga..., dz. cyt., s. 33.

46 Zob. tenże, Wiara, zwątpienie, fanatyzm. Czy trzeba w coś wierzyć?, tłum. B. Jurkevich, Czarna Owca, Warszawa 2016, s. 82. 
Osho uważa też, że religie zawsze potępiały wszystko to, co jest źródłem przyjemności, to znaczy ciało człowieka, instynkt, śmiech i seks, a także muzykę, sztukę, śpiew czy taniec, po to aby ludzie podporządkowali swoje życie konkretnemu ideałowi $\mathrm{i}$ aby $\mathrm{w}$ ten sposób osłabić w nich naturalne popędy. Osho natomiast skłania się ku naturalizmowi etycznemu i dlatego uważa, że wszystko, co jest naturalne, jest również dobre i pomaga w rozwoju człowieka.

\section{Wolność negatywna i pozytywna}

Osho w swoich rozważaniach uwzględnia rozróżnienie na wolność od czegoś i wolność ku czemuś. Podobnie jak Max Stirner, poddaje on krytyce pojęcie tzw. „wolności negatywnej”, czyli wolności „od czegos”” (np. od bycia członkiem własnego narodu, własnej rodziny, partii politycznej czy wyznania religijnego i ideologii politycznej) ${ }^{47}$. Zdaniem Osho nie jest ona „prawdziwą wolnością"48, ale ma charakter relacyjny i warunkowy, ponieważ jest dana jednostce przez coś zewnętrznego w stosunku do niej. Innymi słowy, ma ona zawsze swoją przyczynę w jakiejś rzeczy, od której jednostka czuje się negatywnie zależna i bez pozbycia się której nie byłaby wolna ${ }^{49}$.

Analizując zagadnienie wolności „od”, Osho nawiązuje do stwierdzenia Nietzschego, że Bóg umarł, a w związku z tym człowiek jest wolny ${ }^{50}$. Jego zdaniem takie wyzwolenie ma charakter pozorny, ponieważ nie daje nam żadnego punktu odniesienia, żadnej świadomości czy poczucia odpowiedzialności, a tym samym żadnego rozeznania, co jest dobre i w jakim kierunku powinniśmy podążaćs1. W efekcie człowiek, który nie ma żadnych drogowskazów, może źle użyć nowo zdobytej wolności i zamiast oczekiwanego postępu popaść w rozwiązłość i stoczyć się do poziomu zwierzęcia ${ }^{52}$.

\footnotetext{
47 Zob. tenże, Przygoda bycia sobą. Żyjąc niebezpiecznie, tłum. M. Stefańczuk, Jeden Świat, Warszawa 2019, s. 63.

48 Zob. tenże, Wolność..., dz. cyt., s. 14; tenże, Żyj według własnych zasad. Czym jest prawdziwy bunt?, tłum. B. Jurkevich, Czarna Owca, Warszawa 2016, s. 168.

49 Zob. tenże, Wolność..., dz. cyt., s. 14-15.

50 Zob. tamże, s. 122; tenże, Pytania..., dz. cyt., s. 45.

51 Zob. tenże, Księga zrozumienia..., dz. cyt., s. 140.

52 Zob. tamże.
} 
Dlatego Osho uważa, że wolność „od” nie może stanowić celu samego w sobie ani nie wystarczy, by jednostka mogła realizować siebie i być szczęśliwa ${ }^{53}$. Po co jednostka chce być wolna od czegoś? Co jest celem jej wolności? Jeżeli chce uwolnić się na przykład od wyznawanego dotychczas przesądu, to w opinii Osho powinna uczynić to po to, by móc żyć prawdą. W przeciwnym razie po co miałaby uwalniać się od tych przesądów? ${ }^{54}$. W ten sposób zwraca on uwagę na to, że wprawdzie negatywna wolność jest podstawowym warunkiem naszego rozwoju, ale dopóki nie przyjmiemy sami jakiegoś pozytywnego celu, ona także okazuje się niepełna i daremna ${ }^{55}$, bo nie prowadzi do wykorzystania pełni możliwości, jakie z sobą niesie. Dopiero dopełnienie jej pozytywną wolnością „do czegoś”, przez którą Osho rozumie swobodę, by działać (np. tworzyć, wyrażać siebie), pozwoli urzeczywistnić jej pełny sens ${ }^{56}$. Osho stara się to przedstawić za pomocą obrazowego porównania wolności do uprawy ogródka:

Kiedy przygotowujecie ziemię w ogrodzie, wyrywacie chwasty, niepotrzebne dzikie rośliny i ich korzenie - to jest negatywna część. Ale samo usunięcie chwastów, dzikich roślin i ich korzeni oraz oczyszczenie ziemi nie wystarczy, żeby założyć ogród. Jest konieczne, ale niewystarczające. Będziecie musieli też zasadzić piękne róże; to będzie pozytywna część. Będziecie musieli zasadzić piękne kwiaty, piękne drzewa. Negatywna część tylko przygotowuje do czegoś pozytywnego ${ }^{57}$.

Jednym więc z głównych zadań, jakie stoją przed indywiduum, jest uzyskanie wolności wewnętrznej, której w przekonaniu Osho towarzyszą wewnętrzna harmonia, spokój i duchowa niepodległość rozumiana jako brak uzależnienia. Ma to prowadzić do stania się autonomicznym podmiotem sprawczym, zdolnym do aktywnego kształtowania własnego rozwoju. Kluczową rolę w tym procesie odgrywa postępowanie świadome, które według Osho oznacza robienie czegoś bez wpływu partykularnego ego. Świadomość bowiem uwalnia się wówczas spod panowania „ja”, w wyniku czego następuje zmiana w postrzeganiu - z dotych-

53 Zob. tamże, s. 259; tenże, Empatia. Najpiękniejszy rozkwit miłości, tłum. M. Stefańczuk, Czarna Owca, Warszawa 2013, s. 116-117; tenże, Przygoda bycia..., dz. cyt., s. 63.

54 Zob. tenże, Wolność..., dz. cyt., s. 68; tenże, Buntowniczość: najważniejsza cecha, tłum. A. Staszewska, Nowy Horyzont, Warszawa 2011, s. 71-72.

55 Zob. tenże, Wolność..., dz. cyt., s. 127; tenże, Buntowniczość..., dz. cyt., s. 71, 72.

56 Zob. tenże, Ksiegga zrozumienia..., dz. cyt., s. 259; tenże, Żyj według..., dz. cyt., s. 168; tenże, Przygoda bycia..., dz. cyt., s. 65.

57 Tenże, Wolność..., dz. cyt., s. 128-129; por. z tenże, Buntowniczość..., dz. cyt., s. 73. 
czasowego dualistycznego na niedualistyczne ${ }^{58}$, co pomaga zachować odpowiedni dystans np. do własnych pragnień. Zarówno im nie ulegamy i tym samym nie przejmują one nad nami kontroli i nie stajemy się ich ofiarą, jak również ich w sobie nie tłumimy, lecz zachowujemy równowagę między doświadczeniem radości, którą niosą ze sobą pragnienia, i spokoju, który zapewnia postawa wolna od obsesji ${ }^{59}$. Kiedy tak postępujemy, działamy jako zintegrowane osoby. W efekcie każdy nasz akt będzie aktem wolnym, dokończonym i dobrym. O tym, jaką wartość ma podejmowana przez nas aktywność, decyduje bowiem źródło, z którego ona pochodzi, czyli samo psychologiczne nastawienie podmiotu. Dlatego w osiągnięciu spełnienia istotne jest nie to, co się konkretnie robi, lecz raczej to, $\mathrm{w}$ jaki sposób się to robi: świadomie czy mechanicznie i nawykowo ${ }^{60}$.

Możemy na przykład tworzyć muzykę, pisać wiersze, rzeźbić w marmurze, a więc podejmować jakąś aktywność twórczą, która jest zgodna $z$ naszymi wrodzonymi dyspozycjami, zdolnościami bądź talentami, których realizacja powinna przynieść nam spełnienie i radość. Na urzeczywistnianie własnego potencjału należy jednak spojrzeć w sposób szeroki i nie wiązać go tylko z kwestią konkretnego działania artystycznego sensu stricto ${ }^{61}$. Podobnie jak Maslow, Osho utożsamia proces samorealizacji z twórczością rozumianą egalitarnie, czyli z ekspresją stanu duchowego jednostki przejawiającej się w różnych czynnościach dnia codziennego ${ }^{62}$. Spośród trywialnych, codziennie wykonywanych przez nas czynności (np. picie herbaty) należy, zdaniem Osho, wybrać takie, które są dla nas pod jakimś względem atrakcyjne, a następnie poprzez ich świadome wykonywanie nadać im wewnętrzną jakośćc3 . Dzieje się tak, kiedy wykonujemy coś z pełnym

58 Warto wspomnieć, że na rozumienie przez Osho znaczenia wyzwolenia się spod wpływu „ja” i związane $\mathrm{z}$ tym, podobne do buddyjskiego, doświadczenie całkowitej przemiany widzenia świata - z dwoistego na jedno - wpływ mogła mieć nie tylko jego znajomość filozofii i mistycyzmu Wschodu, ale także doznanie osobistego oświecenia, które zgodnie z jego własnym wyznaniem miało mieć miejsce dnia 21 marca w 1953 roku. Więcej na ten temat zob. tenże, Autobiografia, tłum. Studio Arte, Wydawnictwo KOS, Katowice 2006, s. 70-86.

59 Zob. tenże, Księga ego. Wolność od iluzji, tłum. P. Karpowicz, Czarna Owca, Warszawa 2019, s. $177-178$.

60 Zob. tenże, Ksiegga zrozumienia..., dz. cyt., s. 30, 31.

${ }_{61}$ Zob. tenże, Kreatywność. Uwolnij swą wewnętrzną moc, tłum. B. Jurkevich, M. Stefańczuk, Czarna Owca, Warszawa 2014, s. 97.

62 Zob. M. Derc, Doświadczenie i twórczość w koncepcji Abrahama H. Maslowa, Wyd. UMK, Toruń 1996, s. 82, 89.

63 Zob. Osho, Kreatywność..., s. 97, 98, 130; tenże, Tajemnice życia, tłum. K. Przybyś, Garmond, Warszawa 2007, s. 240, 241. 
zaangażowaniem, skupiając się na tym, co robimy, i wkładając w to uczucie ${ }^{64}$. W rezultacie zwykłe do tej pory czynności mogą stać się na swój sposób niezwykłe, ponieważ dostrzegamy w nich głębię możliwości, jakie z sobą niosą, a nas samych w tym działaniu przepełnia entuzjazm i radość. Jest to w pewnym sensie sposób na to, by w różnych formach mogła się manifestować nasza sfera duchowa, co staje się dla nas sposobnością do uczynienia naszego życia piękniejszym.

Ponadto dla urzeczywistnienia się naszego rozwoju ważna jest także taka aktywność, która rodzi się spontanicznie, ad hoc. To może być zarówno aktywność dotycząca naszego wewnętrznego świata (np. próbujemy osiągnąć wyższy poziom świadomości, uzyskać pełniejsze doświadczenie prawdy, spokoju i harmonii itd.), jak również aktywność skierowana na zewnątrz ${ }^{65}$. Osho przyjmuje realistyczne, integralne rozumienie człowieka, zgodnie z którym to, co materialne, nie jest przeciwstawiane temu, co duchowe ${ }^{66}$. Jego zdaniem obydwa wspomniane wyżej aspekty naszego funkcjonowania uzupełniają się wzajemnie, a jak najpełniejszy rozwój nie może być jednostronny, musi zakładać ich współdziałanie. Są one bowiem jedną energią, stanowią dwa aspekty tego samego bytu ${ }^{67}$. Myślenie w kategoriach konfliktu między tymi dwoma elementami prowadzi do tego, że zajmujemy się jednym z nich za bardzo, innym z kolei niedostatecznie. Podejście syntetyczne pozwala zaś nie lekceważyć żadnego z nich, dzięki czemu doświadczamy wszystkich aspektów życia, znajdując urok i wartość w każdym z nich, a tym samym możemy kształtować jednocześnie różne elementy własnego bytu i rozwijać się jak najpełniej, wielokierunkowo, uzyskując przy tym równowagę mentalną.

\section{Aksjologiczny wymiar wolności człowieka}

Przyjęte przez Osho założenia antropologiczne i ontologiczne stanowią podstawę dla jego etyki, w której formułuje on pewne zalecenia mające na celu pomóc nam w samorealizacji. Jego zdaniem powinniśmy na przykład rozumieć, że wolność zakłada zawsze rzeczywisty wybór między dwiema dostępnymi moż-

\footnotetext{
Zob. tenże, Kreatywność..., dz. cyt., s. 98, 99; tenże, Ksiegga zrozumienia..., dz. cyt., s. 30, 31.

Zob. tenże, Wolność..., dz. cyt., s. 129-131.

Zob. A. Hrehorowicz, Wizja człowieka..., dz. cyt., s. 45, 46, 47.

Zob. Osho, Ksiega zrozumienia..., dz. cyt., s. 27.
} 
liwościami, np. wybrania tego, co jest dobre, lub tego, co złe ${ }^{68}$. Choć wybór zła jest przejawem wolności jednostki, to jednak Osho zaznacza, że należy zdawać sobie sprawę z tego, iż pociąga on za sobą zawsze jakąś negatywną wartość dla jej własnego życia bądź dla drugiego człowieka. Wiele złych wyborów może doprowadzić na przykład do tego, że jednostka zacznie żyć nieautentycznie, uciekać na różne sposoby od odpowiedzialności za siebie, od samej siebie, że zacznie działać mechanicznie, nawykowo, a wtedy samorealizacja nie będzie możliwa. Dlatego Osho uważa, że wolność nie może być jedyną wartością, która determinuje nasze zachowanie. Ona sama nie wystarczy do samorealizacji. Uzyskanie wolności jest tylko pierwszym krokiem, który do niej prowadzi.

Analizując ten problem, Osho dochodzi do wniosku, że wolność należy traktować jako podstawową wartość w życiu człowieka. To dzięki niej może on realizować wszelkie inne wartości i życiowe cele i tym samym zmierzać ku wyższym stopniom rozwoju człowieczeństwa lub degradować swoje życie wewnętrzne, a w skrajnych przypadkach nawet unicestwić samego siebie ${ }^{69}$. Osho ukazuje to za pomocą obrazowej metafory zaczerpniętej z nauczania mistyków Wschodu, w której porównuje on wolność do drabiny:

Wolność daje ci możliwość, byś upadł niżej niż zwierzęta lub wzniósł się wyżej niż anioły. Wolność jest drabiną. Jeden jej koniec sięga piekła, drugi dotyka nieba. Jest to jedna drabina; wybór należy do ciebie, ty musisz wybrać kierunek $^{70}$.

Stąd też w założeniu Osho zrozumienie istoty wolności nie jest zagadnieniem czysto teoretycznym. Jest to bowiem podstawowa wartość, która określa nasze wybory i decyzje, jest więc kluczowa z punktu widzenia naszego własnego rozwoju i zdolności pokierowania naszym życiem tak, abyśmy w konkretnej sytuacji mogli z niej uczynić właściwy użytek.

Osho zwraca uwagę na to, że jest to jednak problem złożony i poniekąd dramatyczny. Aby się rozwijać, musimy dokonywać wyborów, nie jesteśmy

68 Zob. tenże, Psychologia..., dz., cyt., s. 20; tenże, Dojrzałość. Odpowiedzialność bycia sobą, tłum. B. Jurkevich, M. Stefańczuk, Garmond, Warszawa 2006, s. 151; tenże, Miłość, wolność..., dz. cyt., s. 136, 137; tenże, Przeznaczenie..., dz. cyt., s. 182, 183; tenże, Ksiega ego..., dz. cyt., s. 173-174. Zob. tenże, Transformacja..., dz. cyt., s. 58; tenże, Wejdź głębiej, bądź naturalny, sięgnij wyżej, tłum. A. Staszewska, Nowy Horyzont, Warszawa 2011, s. 32.

70 Tenże, Miłość, wolność..., dz. cyt., s. 137; por. z tenże, Psychologia..., dz. cyt., s. 20; tenże, Wejdź głębiej..., dz. cyt., s. 32-33; tenże, Przeznaczenie..., dz. cyt., s. 184; tenże, Księga ego..., dz. cyt., s. 174; tenże, Naucz się być sobą, tłum. A. Staszewska, Nowy Horyzont, Warszawa 2012, s. 16. 
jednak wszechwiedzący i nieomylni. W momencie podejmowania decyzji nie mamy żadnej pewności, że będzie ona właściwa i że obraliśmy słuszny kierunek działania. Dlatego Osho mówi, że w życiu możemy nawet wiele razy mylić się i popełniać błędy ${ }^{71}$, że z wolnością immanentnie związane jest ryzyko zbłądzenia $^{72}$ i dlatego stanowi ona „niebezpieczny fenomen”. Radzi on, aby traktować ją jako swego rodzaju wyzwanie, któremu trzeba sprostać:

Wolność oznacza chodzenie po ostrzu brzytwy - w każdej chwili jesteś w niebezpieczeństwie, torujesz sobie drogę. Każdy moment jest wyzwaniem od nieznanego $^{73}$.

Ponadto radzi on, żeby w momencie dokonywania wyboru podążać za swoją intuicją. Chociaż nie jest to nieomylny przewodnik i nie mamy gwarancji, że dzięki temu będziemy zawsze wybierać trafnie, nie powinniśmy $\mathrm{z}$ tego powodu mieć poczucia winy. Popełnianie błędów jest bowiem integralną częścią procesu wzrastania, rozwoju i uczenia się ${ }^{74}$. Dzięki nim stajemy się przenikliwi i odpowiedzialni. Złe wybory, upadki i błędy motywują nas do refleksji, wyostrzają naszą inteligencję i zwiększają świadomość tego, co i po co coś robimy, dzięki czemu stopniowo uświadamiamy sobie, kim jesteśmy, zaczynamy podążać we właściwym kierunku i odnajdujemy swoją drogę $e^{75}$.

Celem Osho nie jest więc przesadne akcentowanie niedogodności związanych z ludzką wolnością, ale raczej ukazanie jej jako żywego konkretu i podkreślenie jej związku z wartościami. Jest to zarazem punkt wyjścia do rozważań poświęconych etycznemu wymiarowi samorealizacji. Przyjrzyjmy się teraz bliżej temu zagadnieniu. Dotychczasowa analiza aksjologicznego aspektu wolności pozwala wnioskować, że wolność jest przez Osho rozumiana jako możliwość dokonywania przez podmiot świadomych, intencjonalnych wyborów mających wpływ na nasze życie. Nie musimy przecież być np. nieszczęśliwi. Jeżeli jesteśmy wolnymi ludźmi, to powinniśmy wiedzieć, że w głównej mierze wyłącznie od nas

\footnotetext{
Zob. tenże, Pytania..., dz. cyt., s. 179; tenże, Buntowniczość..., dz. cyt., s. 16.

Zob. tenże, Przeznaczenie..., dz. cyt., s. 23.

Tenże, Wolność..., dz. cyt., s. 57.

Zob. tenże, Naucz się..., dz. cyt., s. 98-99; tenże, Buntowniczość..., dz. cyt., s. 16.

Zob. tenże, Wolność..., dz. cyt., s. 175; tenże, Przeznaczenie..., dz. cyt., s. 21, 23; tenże, Równowaga..., dz. cyt., s. 47; tenże, Pytania..., dz. cyt., s. 52-53.
} 
samych zależy, jakiego dokonamy wyboru: czy chcemy czuć się szczęśliwi, czy nieszczęśliwi ${ }^{76}$. Osho podkreśla to wyraźnie:

Nie możesz powiedzieć, że ktoś inny cię do tego zmusił - bo jesteś wolny; nikt cię nie może zmusić! Ponieważ jesteś wolny, sam decydujesz, czy coś zrobisz, czy nie ${ }^{77}$.

Jeżeli chcemy się rozwijać, to wolność musi być zdaniem Osho tożsama z wzięciem przez nas pełnej odpowiedzialności za samych siebie ${ }^{78}$. Sprawia to, że możemy refleksyjnie podejść do siebie samych i swojego życia, i wobec tego zyskać nad nim kontrolę. Dzięki temu pojęcie „samorealizacji” zyskuje sens etyczny.

Osho głosi zatem, że powinniśmy zrozumieć wartość związku łączącego wolność z odpowiedzialnością, gdyż one wzajemnie się warunkują: „Im bardziej odpowiedzialny się stajesz, tym bardziej stajesz się wolny"79. Dzieje się tak, gdyż zaakceptowanie odpowiedzialności za siebie wprowadza nas w wymiar świadomego postępowania, które Osho utożsamia z cnotą. To ono uczy nas umiejętności zachowania pewnego rodzaju wewnętrznej dyscypliny. Rozważa on to pojęcie, podobnie jak i pojęcie „odpowiedzialności”, nie w kontekście etyki deontologicznej, bazującej na „powinności”, ale raczej w odniesieniu do autentycznie przeżywanej egzystencji. Dyscyplina ta polega na tym, że samodzielnie uczymy się troszczyć o siebie i kierować swoim życiem nie na zasadzie działania według reguł wynikających $\mathrm{z}$ obowiązującego w danym społeczeństwie kodu moralnego, lecz mając wgląd $\mathrm{w}$ istotę sytuacji dziejącej się hic et nunc ${ }^{80}$. Zdajemy sobie sprawę z tego, że nasze działania pociągają za sobą jakieś skutki dla naszego życia i rozwoju. Dlatego dążymy do takiego sposobu używania swojej wolności, żeby podjęte decyzje i wybory nie narzucały nam ograniczeń, lecz dawały nam możliwość kolejnych swobodnych wyborów ${ }^{81}$. We wcześniejszym paragrafie wspomniałem, że sama wolność bez odpowiedzialności za siebie może przerodzić się w niszczącą dla nas siłę. Dlatego Osho uważa, że jeśli zrozumiemy wartość tej

\footnotetext{
76 Zob. tenże, Radość. Poczucie szczęścia, które masz w sobie, tłum. B. Jurkevich, Czarna Owca, Warszawa 2013, s. 8; tenże, Księga ego..., dz. cyt., s. 175; tenże, Świadomość. Klucz do życia w równowadze, tłum. B. Jurkevich, M. Stefańczuk, Czarna Owca, Warszawa 2013, s. 136.

77 Tenże, Wolność..., dz. cyt., s. 122.

78 Zob. tamże, s. 132; tenże, Naucz się..., dz. cyt., s. 16; tenże, Tajemnice..., dz. cyt., s. 209; A. Hrehorowicz, Aksjologiczne..., dz. cyt., s. 268.

79 Osho, Wolność..., dz. cyt., s. 124; por. z tenże, Przygoda bycia..., dz. cyt., s. 62.

80 Zob. tenże, $\dot{Z} y j$ według..., dz. cyt., s. 160.

81 Zob. tenże, Przeznaczenie..., dz. cyt., s. 229.
} 
odpowiedzialności, to na pewno nie upadniemy poniżej poziomu zwierzęcia, lecz będziemy wzrastać. Dyscyplina bowiem pozwala nam zachować na tyle głęboką świadomość i uważność w tym, co robimy i mówimy, że nie jesteśmy w stanie wyrządzić krzywdy sobie czy innym. W związku z tym można uznać, że zalecana przez Osho wewnętrzna dyscyplina stanowi jedną z ogólnych zasad jego etyki, gdyż sprzyja aktualizowaniu się jak najpełniej naszego potencjału. Sama aktualizacja może przebiegać przy tym tak, by nie szkodziło to nam samym, a także innym ludziom.

\section{Społeczny wymiar samorealizacji człowieka}

Innym ważnym założeniem filozoficznym, na którym opiera się koncepcja samorealizacji człowieka u Osho, jest przekonanie o holistycznej strukturze świata. Według niego świat jest organiczną całością, która zakłada harmonijne współwystępowanie wszystkich bytów, w tym człowieka ${ }^{82}$. Indywidualne życie człowieka jest cząstkowe wobec bytu jako całości. Dlatego też jest ono przede wszystkim życiem społecznym, które kształtuje się poprzez spotkania międzyludzkie. Nasz naturalny potencjał aktualizuje się nie tylko w wyniku naszej bezpośredniej aktywności, ale również w efekcie oddziaływań innych ludzi czy środowiska przyrodniczego, w którym żyjemy. Ponadto zawiera on takie predyspozycje, dla realizacji których potrzebujemy uczestnictwa i pomocy ze strony innych osób. Człowiek może na przykład śmiać się samotnie, jednak nie będzie w stanie doświadczyć w ten sposób współczucia czy empatii ${ }^{83}$. Jeśli zatem chcemy uzyskać jak najpełniejsze ukonstytuowanie swojego człowieczeństwa, to zdaniem Osho powinniśmy próbować rozumieć swoje jednostkowe życie jako istotnie splecione $\mathrm{z}$ życiem $\mathrm{w}$ ogóle. $\mathrm{W}$ ten sposób, realizując swój rozwój, odnosimy go do bytu w ogóle, dzięki czemu uzyskujemy i stosujemy w praktyce najogólniejszą wiedzę. Człowiek, który widzi siebie jako tego, kto istnieje pośród całości bytu i doświadcza swojego istnienia jako zanurzonego w nim, postrzega jednocześnie, że w tej wspólnej rzeczywistości istnieją także inne konkretne byty, zdarzenia i sytuacje (np. drugi człowiek, świat przyrody, rzeczy itd.), które również par-

82 Zob. tenże, Medytacja: pierwsza i ostatnia wolność. Praktyczny przewodnik, tłum. J. Grabiak, Rebis, Poznań 2002, s. 306-307, 321-322; tenże, Medytacja dla zabieganych. Jak odnaleźć wewnętrzna ciszę w zgiełku codzienności, tłum. B. Jurkevich, Czarna Owca, Warszawa 2019, s. 39.

Zob. A. Hrehorowicz, Aksjologiczne..., dz. cyt., s. 254. 
tycypują w większej całości i które mogą mieć pewną wartość dla jego rozwoju. Przyjmując taką holistyczną perspektywę, zaczyna on rozumieć, że ta relacja jest wzajemna. Takie całościowe spojrzenie sprzyja nie tylko wzrostowi jednostki, ale podtrzymuje także harmonijną współzależność wszystkich bytów, podtrzymuje je w trwaniu i pomaga im w ich rozwoju.

To oparte na holistycznym pojmowaniu świata ujęcie relacji człowieka do świata prowadzi do redefinicji i poszerzenia zakresu znaczeniowego pojęcia „samorealizacja”. Przekracza ono dualizm tego, co indywidualne, i tego, co zbiorowe, i zyskuje ostatecznie wymiar metafizyczno-kosmiczny. Samorealizacja oznacza wtedy funkcjonowanie i rozwój jednostki w harmonii z całym istnieniem. Źródłem tej samorealizacji jest miłość pojmowana przez Osho jako „transcendentny" stan świadomości człowieka. Wraz z tą odmianą miłości pojawia się w nim także otwartość, współczucie i wrażliwość na otaczający go świat, których dotąd tak wyraźnie w sobie nie odczuwał:

Stajesz się tak wrażliwy, że nawet najmniejsze źdźbło trawy nabiera dla ciebie znaczenia. Twoja wrażliwość uzmysławia ci, że to małe źdźbło trawy jest tak samo ważne jak największa gwiazda - bez niego egzystencja byłaby niekompletna. To małe źdźbło trawy jest wyjątkowe, niezastąpione, posiada swoją własną indywidualność ${ }^{84}$.

Wydaje się zatem, że miłość jest tutaj wartością ściśle poznawczą, gdyż umożliwia jednostce odkrywanie prawdy poprzez własne doświadczenia nowych obszarów bytu, które w tym procesie stają się jaśniejsze i bardziej zrozumiałe. Poznanie prawdy ma charakter wyłącznie egzystencjalny bądź mistyczny, ponieważ w przekonaniu Osho działanie miłości otwiera człowieka głębiej na poznanie bytu. Przez „otwartość” należy tutaj rozumieć swobodne dążenie do doświadczania coraz większych obszarów bytu, w którym uczestniczymy, dzięki czemu zyskujemy dostęp do dotychczas nieznanych jego aspektów bądź stają się one dla nas dostępne w inny niż dotychczas sposób. Według Osho moc miłości otwiera człowieka na postrzeganie swojego życia jako zjednoczonego z całą egzystencją i nadaje określony cel indywidualnemu rozwojowi:

Im wrażliwszy się stajesz, tym bardziej poszerza się twoje życie. Nie jest już małym stawem, urasta do oceanicznych rozmiarów. Nie ogranicza się do cie-

84 Osho, Dojrzałość..., dz. cyt., s. 12. 
bie, twojej żony, dzieci; nie jest ograniczone niczym ani nikim. Cała egzystencja staje się twoją rodziną. Dopóki tak się nie stanie, nie wiesz, co to znaczy życie; człowiek nie jest przecież wyspą, wszyscy jesteśmy połączeni. Stanowimy ogromny kontynent i jesteśmy połączeni na miliony sposobów. A jeżeli nasze serca nie są pełne miłości do wszystkiego wokół, tak samo niepełne jest nasze życie. Medytacja rozbudzi twoją wrażliwość, da ci wspaniałe uczucie bycia cząstką świata. To przecież nasz świat, nasze gwiazdy; nie jesteśmy tu obcy. Nieodłącznie przynależymy do całej egzystencji. Jesteśmy jej składnikiem, jej sercem $^{85}$.

Według Osho poznanie siebie jako cząstki całego istnienia umożliwia więc nam przeżycie misteryjności i mistyczności. Prowadzi ono bowiem do przyjęcia przez nas postawy celebracji istnienia. Jest to radosny sposób podejścia do życia, który zdaniem Osho wyraża naszą głęboko przeżywaną miłość i szacunek do niego ${ }^{86}$. Dlatego celebracja dotyczy akceptacji życia jako całości, to znaczy doświadczania go w jego różnych przejawach i życia jego pełnią, by w wyniku tego osiągnąć wewnętrzne bogactwo i różnorodność.

Podkreślanie przez Osho znaczenia współzależności człowieka ze światem nie ogranicza się tylko do metafizycznego aspektu ludzkiej egzystencji. Wskazuje ono także na rolę wzajemnej współzależności wszystkich ludzi w dążeniu etycznym, podkreślając $\mathrm{w}$ ten sposób związek samorealizacji $\mathrm{z}$ etyką. Jak już zostało nadmienione, działając $\mathrm{w}$ harmonii ze światem, osoba osiąga wewnętrzne poczucie pełni ${ }^{87}$, w wyniku którego pojawia się $\mathrm{w}$ niej silne poczucie radości, spokoju i szczęścia, którym pragnie dzielić się bezinteresownie z innymi ludźmi ${ }^{88}$. Ta potrzeba „podzielenia się sobą” z innymi jest tym silniejsza, im silniejsza jest miłość osoby do życia i tym samym głębsze jest jej zrozumienie znaczenia występującej w nim współzależności. Osho uważa, że jedynie ludzie spełnieni są w stanie pozytywnie wpływać na odczucia innych oraz wspomagać ich rozwój duchowy, akceptując przy tym ich wolność i pozwalając, by byli sobą. Dzięki

\footnotetext{
85 Tamże, s. 13; por. z tenże, Buntowniczość..., dz. cyt., s. 17; tenże, Przygoda bycia..., dz. cyt., s. 83.

86 Zob. tenże, Tajemnice..., dz. cyt., s. 31-33.

87 Zob. tenże, Księga zrozumienia..., dz. cyt., s. 70.

88 Zob. tenże, Żyj wedtug..., dz. cyt., s. 176. W rozważaniach Osho odnajdujemy pewną analogię do poglądów Nietzschego, który także uważa umiejętność bezinteresownego obdarowywania za wartość etyczną. Istota tego bezinteresownego aktu tkwi w utożsamieniu celu z samym działaniem, przynoszącym radość działającemu człowiekowi (A. Hrehorowicz, Wizja człowieka..., dz. cyt., s. 107-108).
} 
temu między uczestnikami takiej relacji pojawia się wzajemne zaufanie, emocjonalna intymność i szacunek. A to z kolei wzbogaca ich wewnętrznie i przynosi obopólne zadowolenie. Dlatego według Osho bogactwo wewnętrzne osoby jest zaprzeczeniem egoizmu, co należy uważać właśnie za wartość etyczną. Jeśli ktoś prawdziwie kocha siebie i afirmuje swoje istnienie, to nie będzie dążył wyłącznie do własnego rozwoju i do zachowania samego siebie, będzie bowiem chciał, aby ten stan udzielił się wszystkim ludziom w jego otoczeniu ${ }^{89}$. Ma on świadomość współzależności łączącej go z innymi ludźmi. Dlatego nie może być prawdziwie szczęśliwy, kiedy inni wokół niego są nieszczęśliwi i smutni. Zarówno radość, jak i smutek są zaraźliwe, będą się udzielać ${ }^{90}$. Człowiek będzie szczęśliwy tylko wtedy, kiedy inni wokół niego też będą szczęśliwi.

Kolejne zalecenie etyczne, które pomaga człowiekowi w samorealizacji, zakłada, że jeśli człowiek chce czuć się szczęśliwy, to powinien zacząć przywiązywać wagę do tego, czy inni ludzie wokół niego też są szczęśliwi ${ }^{11}$. Postawa taka nie pozbawia żadnej ze stron możliwości realizacji własnej indywidualności w relacjach, a jednocześnie prowadzi do uzyskania harmonijnego współbycia i daje poczucie sensu, jakie z niego wynika. Na znaczenie tej współzależności w życiu etycznym zwróciło wcześniej uwagę kilku innych myślicieli, np. Martin Heidegger w swojej idei „Das Mitsein”. Współzależność taka pełni w myśli Osho kluczową funkcję w dążeniu etycznym człowiek $a^{92}$. Jest tak, ponieważ poza społeczeństwem człowiek nie będzie w stanie rozwinąć wartości niezbędnych dla życia etycznego - nie stanie się ani naprawdę wolny, ani odpowiedzialny. Tworzy ono bowiem kontekst dla naszej przemiany i rozwoju ${ }^{93}$. Z faktu współzależności można też wyprowadzić najważniejszą zasadę etyki Osho, która zakłada, że należy aktualizować własny, naturalny potencjał w taki sposób, by jednocześnie wspomagać aktualizowanie cudzych możności, dyspozycji i talentów. Wiąże się $\mathrm{z}$ nią postulat nieinstrumentalnego traktowania drugiej osoby, tak aby stosunki międzyludzkie przybrały formę współpracy szanujących się ludzi.

\footnotetext{
Zob. A. Hrehorowicz, Wizja człowieka..., dz. cyt., s. 108.

Zob. Osho, Transformacja..., dz. cyt., s. 244; tenże, Żyj wedtug..., dz. cyt., s. 166; tenże, Empatia..., dz. cyt., s. 53.

Zob. A. Hrehorowicz, Aksjologiczne..., dz. cyt., s. 255.

Zob. tamże.

Zob. Osho, Buntowniczość..., dz. cyt., s. 74, 76, 77.
} 


\section{Zakończenie}

W powyższych rozważaniach przedstawione zostały najważniejsze założenia filozoficzne koncepcji samorealizacji u Osho. Choć pojęcie to jest obecnie modne, filozofowie patrzą na nie niekiedy bez sympatii, mając - często słuszne - podejrzenie, że wywodzi się ono z takich popularnych współcześnie nurtów jak chociażby New Age. Mam nadzieję, że niniejszy tekst jasno pokazał, że u podstaw koncepcji Osho leży jednak myślenie par excellence filozoficzne. Jest w niej na tyle dużo różnych filozoficznych wątków i odniesień, że taką interpretację, która łączyłaby ją wyłącznie z rozmaitymi teoriami rozwoju osobistego, należałoby uznać za uproszczoną i błędną.

Filozof ten konsekwentnie postrzega człowieka jako integralny byt, którego natura ma charakter ewolucyjny. Szczególne znaczenie mają tutaj również takie wartości, jak świadomość, wolność, odpowiedzialność czy założenie o współzależności istot ludzkich. Zrozumienie ich roli w życiu ludzkim jest kluczowe dla zrekonstruowania koncepcji samorealizacji, którą Osho rozpatruje zarówno $\mathrm{w}$ aspekcie ontologicznym, jak i etycznym. Świadomość tworzy indywidualność, jest źródłem wolności i odpowiedzialności, w efekcie czego człowiek jest wolnym podmiotem sprawczym, indywidualnie odpowiedzialnym przed samym sobą za swój twórczy rozwój. Trzeba jednak podkreślić, że pomimo tego wyjściowego indywidualizmu nie mamy tutaj do czynienia $z$ egoizmem i stawianiem na samodoskonalenie się w oderwaniu od altruizmu czy wartości społecznych. Ze względu na holistyczny sposób ujmowania relacji człowieka ze światem i przyjęcie założenia o współzależności istot ludzkich ta koncepcja samorealizacji jest bowiem otwarta także na wymiar społeczny, umożliwiający tworzenie wspólnoty i akcentujący wartość partnerskich relacji z innymi jednostkami.

\section{Bibliografia}

Buber M., Problem człowieka, tłum. J. Doktór, Wyd. Naukowe PWN, Warszawa 1993.

Chryssides G.D., Exploring New Religions, wyd. Continuum International Publishing Group, London 1999. 
Derc M., Doświadczenie i twórczość w koncepcji Abrahama H. Maslowa, Wyd. UMK, Toruń 1996.

Hrehorowicz A., Aksjologiczne źródła etyki u Osho, „Humanistyka i Przyrodoznawstwo" 2017, nr 23, s. 253-271, https://doi.org/10.31648/hip.328.

Hrehorowicz A., Wizja człowieka u Osho, Wyd. Eryk Kowalczyk, Olsztyn 2016. Jaroszewski T., Filozofia egzystencji a etyka sytuacyjna Jean Paul Sartre’a, „Etyka” 1970, nr 7, s. 39-75.

Joshi V., The Awakened One, Harper and Row, San Francisco 1982.

Kudelska M., Filozofia Indii - kilka uwag wstępnych, w: Filozofia Wschodu, red. B. Szymańska, Wydawnictwo Uniwersytetu Jagiellońskiego, Kraków 2001.

Nietzsche F., Tako rzecze Zaratustra. Książka dla wszystkich i dla nikogo, tłum. W. Berent, Zysk i S-ka, Poznań 2005.

Nietzsche F., Wiedza radosna, tłum. L. Staff, Zielona Sowa, Kraków 2003.

Nysler Ł., Natura ludzka - jaźń - indywidualność. Filozoficzno-antropologiczne i etyczne podstawy koncepcji demokracji Johna Deweya, „Studia Philosophica Wratislaviensia" 2007, vol. II, fasc. 1, s. 55-76.

Osho, Autobiografia, tłum. Studio Arte, Wydawnictwo KOS, Katowice 2006.

Osho, Buntowniczość: najważniejsza cecha, tłum. A. Staszewska, Nowy Horyzont, Warszawa 2011.

Osho, Dojrzałość. Odpowiedzialność bycia soba, tłum. B. Jurkevich, M. Stefańczuk, Garmond, Warszawa 2006.

Osho, Empatia. Najpiękniejszy rozkwit miłości, tłum. M. Stefańczuk, Czarna Owca, Warszawa 2013.

Osho, Kreatywność. Uwolnij swą wewnętrzna moc, tłum. B. Jurkevich, M. Stefańczuk, Czarna Owca, Warszawa 2014.

Osho, Księga ego. Wolność od iluzji, tłum. P. Karpowicz, Czarna Owca, Warszawa 2019.

Osho, Księga zrozumienia. Własna droga do wolności, tłum. B. Grabska-Siwek, Czarna Owca, Warszawa 2013.

Osho, Magia szacunku do siebie. Rozbudzanie świadomości, tłum. B. Jurkevich, Czarna Owca, Warszawa 2020.

Osho, Medytacja dla zabieganych. Jak odnaleźć wewnętrzna ciszę w zgiełku codzienności, tłum. B. Jurkevich, Czarna Owca, Warszawa 2019.

Osho, Medytacja: pierwsza i ostatnia wolność. Praktyczny przewodnik, tłum. J. Grabiak, Dom Wydawniczy „Rebis”, Poznań 2002. 
Osho, Miłość, wolność, samotność. Nowe spojrzenie na związki między ludźmi, tłum. B. Jurkevich, Czarna Owca, Warszawa 2015.

Osho, Naucz się być sobą, tłum. A. Staszewska, Nowy Horyzont, Warszawa 2012. Osho, Przeznaczenie, wolność, dusza. Jaki sens ma życie?, tłum. B. Jurkevich, Czarna Owca, Warszawa 2017.

Osho, Przygoda bycia sobą. Żyjąc niebezpiecznie, tłum. M. Stefańczuk, Jeden Świat, Warszawa 2019.

Osho, Psychologia ezoteryki, tłum. i wyd. Samira, Łódź 1995.

Osho, Pytania płynące z serca, tłum. B. Jurkevich, Czarna Owca, Warszawa 2019.

Osho, Radość. Poczucie szczęścia, które masz w sobie, tłum. B. Jurkevich, Czarna Owca, Warszawa 2013.

Osho, Równowaga ciała i umysłu, tłum. B. Jurkevich, Ravi, Łódź 2005.

Osho, Świadomość. Klucz do życia w równowadze, tłum. B. Jurkevich, M. Stefańczuk, Czarna Owca, Warszawa 2013.

Osho, Tajemnice życia. Wprowadzenie do nauk Osho, tłum. K. Przybyś, Garmond, Warszawa 2007.

Osho, Transformacja przez tantrę, tłum. H. Smagacz, Nowy Horyzont, Warszawa 2010.

Osho, Wejdź głębiej, bądź naturalny, sięgnij wyżej, tłum. A. Staszewska, Nowy Horyzont, Warszawa 2011.

Osho, Wiara, zwatpienie, fanatyzm. Czy trzeba w coś wierzyć?, tłum. B. Jurkevich, Czarna Owca, Warszawa 2016.

Osho, Wielka księga sekretów, tłum. J. Janisiewicz, Czarna Owca, Warszawa 2011.

Osho, Wolność. Odwaga bycia sobq, tłum. H. Smagacz, Czarna Owca, Warszawa 2014.

Osho, Zaratustra: Bóg, który tańczyć potrafi. Komentarz do „Tako rzecze Zaratustra Friedricha Nietzschego, tłum. Studio Arte, Wydawnictwo KOS, Katowice 2007.

Osho, Życiejako podróż. Czy można znaleźć prawdziwe szczęście w codzienności?, tłum. B. Jurkevich, Czarna Owca, Warszawa 2018.

Osho, Żyj według własnych zasad. Czym jest prawdziwy bunt?, tłum. B. Jurkevich, Czarna Owca, Warszawa 2016.

Sartre J.-P., Egzystencjalizm jest humanizmem, tłum. J. Krajewski, Warszawskie Wyd. Literackie Muza, Warszawa 1998. 
Schweer T., Hinduizm: powstanie - dzieje - nauka, tłum. P. Pachciarek, Wydawnictwo Verbinum, Warszawa 2003.

Sieradzan J., Ośo Radżniś, czyli szaleństwo jako metoda, w: tegoż, Od kultu do zbrodni. Ekscentryzm i szaleństwo w religiach XX wieku, Wydawnictwo KOS, Katowice 2006, s. 115-189.

Świtkowski J., Kwiaty lotosu i kundalini a gruczoły dokrewne - studium krytyczne, Lotos, Kraków 1937.

Urban H.B., Zorba the Buddha Capitalism, Charisma and the Cult of Bhagwan Shree Rajneesh, „Religion” 1996, nr 26, s. 161-182.

\section{Streszczenie}

Artykuł omawia istotne filozoficzne założenia koncepcji samorealizacji w myśli Osho. Zasadniczą tezą pracy jest stwierdzenie, że wspomniana teoria wspiera się na przyjętej przez filozofa ewolucyjnie pojętej wizji natury ludzkiej. W wyniku tego samorealizacja jest wyrażana przez podmiot samodzielnie i świadomie jako ukierunkowany i zamierzony proces pełnej formacji ludzkości. Zważywszy także na przyjęte przez Osho założenie o holistycznej strukturze świata, zgodnie z którym współistnienie istot ludzkich na pewnych poziomach wiąże się z wzajemnym oddziaływaniem, samorealizacja ma u niego sens nie tylko ontologiczny, lecz również zyskuje znaczenie etyczne, ponieważ wymaga ona od podmiotu kształtowania świadomej i odpowiedzialnej za osobisty rozwój postawy dla dobra własnego oraz innych.

Słowa kluczowe: natura ludzka, samorealizacja, świadomość, odpowiedzialność, wolność 


\section{Summary}

\section{Philosophical Foundations of Osho's Concept of Human Self-realization}

The article analyzes the philosophical assumptions regarding the concept of selfrealization in Osho's thought. The main thesis of the study is the statement that the theory is based on the evolutionary vision of human nature accepted by the author. As a result, self-realization is expressed independently and consciously by the subject as a directed and intended process of complete formation of the humanity. Considering Osho's assumption about the holistic structure of the world, according to which the coexistence of human beings on certain levels is connected with interaction, self-realization has not only an ontological sense, but also gains an ethical meaning because it tends to shape a conscious and responsible attitude for the personal development, in the subject's and others' best interest.

Key words: human nature, self-fulfillment, consciousness, responsibility, freedom 